\title{
Inclusion of Citrullus colocynthis Seed Extract into Diets Induced a Hypolipidemic Effect and Improved Layer Performance
}

\author{
Mohamed I. Alzarah ${ }^{1}\left(\mathbb{D}\right.$, Abdulaziz A. Alaqi1 ${ }^{2}$, Ahmed O. Abbas ${ }^{2,3}$, Farid S. Nassar ${ }^{3}$, Gamal M. K. Mehaisen ${ }^{3, *} *$, \\ Gouda F. Gouda ${ }^{4}$, Hanaa K. Abd El-Atty ${ }^{5}$ and Eman S. Moustafa ${ }^{3}$ (i) \\ 1 Department of Environmental and Natural Resources, College of Agricultural and Food Sciences, \\ King Faisal University, P.O. Box 420, Al-Ahsa 31982, Saudi Arabia; malzarah@kfu.edu.sa \\ 2 Department of Animal and Fish Production, College of Agricultural and Food Sciences, \\ King Faisal University, P.O. Box 420, Al-Ahsa 31982, Saudi Arabia; aalaqil@kfu.edu.sa (A.A.A.); \\ aabbas@kfu.edu.sa (A.O.A.) \\ 3 Department of Animal Production, Faculty of Agriculture, Cairo University, Gamma Street, \\ Giza 12613, Egypt; Fidsaber_nassar@agr.cu.edu.eg (F.S.N.); emansm23@agr.cu.edu.eg (E.S.M.) \\ 4 Animal Breeding Section, Department of Animal Production, Faculty of Agriculture, Ain Shams University, \\ P.O. Box 68, Haddaik Shoubra 11241, Cairo, Egypt; gouda_fathi@yahoo.com \\ 5 Department of Poultry Breeding, Animal Production Research Institute, Agricultural Research Center, Dokki, \\ Giza 12611, Egypt; Hanaa.amin@arc.sci.eg \\ * Correspondence: gamoka@cu.edu.eg; Tel.: +20-122-679-7270
}

check for updates

Citation: Alzarah, M.I.; Alaqil, A.A.; Abbas, A.O.; Nassar, F.S.; Mehaisen, G.M.K.; Gouda, G.F.; Abd El-Atty, H.K.; Moustafa, E.S. Inclusion of Citrullus colocynthis Seed Extract into Diets Induced a Hypolipidemic Effect and Improved Layer Performance. Agriculture 2021, 11, 808. https:// doi.org/10.3390/agriculture11090808

Academic Editor: István Komlósi

Received: 13 July 2021

Accepted: 24 August 2021

Published: 26 August 2021

Publisher's Note: MDPI stays neutral with regard to jurisdictional claims in published maps and institutional affiliations.

Copyright: (c) 2021 by the authors Licensee MDPI, Basel, Switzerland. This article is an open access article distributed under the terms and conditions of the Creative Commons Attribution (CC BY) license (https:// creativecommons.org/licenses/by/ $4.0 /)$.
Abstract: Citrullus colocynthis (CC) has been known as a natural medicinal plant with wide biological activities, including antioxidant, anti-inflammatory, and antilipidemic effects. The aim of this study was to investigate the effect of inclusion of the ethanolic extract of CC seeds (ECCs) into layer diets on the lipid profile, stress indicators, and physiological and productive performance of laying hens. A total of 216 forty-week-old commercial Hy-Line brown laying hens were randomly assigned into four equal groups ( 3 birds $\times 18$ replicates per group) that received a basal diet supplemented with $0,0.5,1.0$, and $2.0 \mathrm{~g} / \mathrm{kg}$ of ECCs for 12 consecutive weeks. The first group served as a control. The results showed that ECCs at 1.0 and $2.0 \mathrm{~g} / \mathrm{kg}$ significantly $(p<0.05)$ improved the productive and physiological performance compared to the other groups. In addition, stress indicators examined in the laying hens, including lipid peroxidation (malondialdehyde (MDA)), corticosterone hormone (CORT), tumor necrosis factor alpha (TNF $\alpha$ ), and heat shock protein 70 (HSP70), were significantly alleviated after inclusion of ECCs into layer diets at the three levels compared to the control group. Furthermore, all ECC levels induced a significant reduction in plasma triglyceride (TG) and cholesterol (CH) levels in the plasma, liver, and egg yolk, whereas the highest levels were obtained with $2.0 \mathrm{~g} / \mathrm{kg}$ of ECCs. Particularly important, a high linear correlation $\left(\mathrm{R}^{2}=0.60-0.79\right)$ was observed between increasing doses of ECCs and MDA, liver $\mathrm{CH}$, and egg yolk $\mathrm{CH}$ concentrations and egg weight, feed intake, and feed conversion ratio; moreover, the correlation was extremely high $\left(\mathrm{R}^{2}=0.80-0.100\right)$ with the level of TG, $\mathrm{CH}$, low-density lipoprotein $\mathrm{CH}$, high-density lipoprotein $\mathrm{CH}$, and CORT. These results indicated that dietary supplementation with $2.0 \mathrm{~g} / \mathrm{kg}$ of ECCs could be considered a successful nutritional approach to producing healthier, lower-cholesterol eggs for consumers, in addition to enhancing the physiological and productive performance of laying hens by alleviating the stress of intensive commercial production.

Keywords: Citrullus colocynthis; lipid profile; stress indicators; physiological status; productive performance; laying hens

\section{Introduction}

Commercial egg production has become a substantial trend in the poultry industry because chicken eggs provide a valuable source of high-quality nutrients for human food 
and health, including proteins, fatty acids, vitamins, and minerals [1]. However, the consumption of foods rich in dietary cholesterol may increase the cholesterol $(\mathrm{CH})$ levels in the individual blood and low-density lipoprotein particles [2]. These events can be associated with a high incidence of atherosclerotic cardiovascular disease (CVD), especially in old-aged individuals $[3,4]$. Chicken egg yolks are a major source of dietary $\mathrm{CH}$ in the human diet (200 $\mathrm{mg}$ of $\mathrm{CH}$ per one large egg yolk) and contribute approximately $25 \%$ of the daily $\mathrm{CH}$ consumption in both children and adults in Western countries [5,6]. Egg consumption in old-aged or diabetic individuals shows a significant increase in serum $\mathrm{CH}$ in low-density lipoprotein cholesterol (LDL-CH) than in high-density lipoprotein cholesterol (HDL-CH), resulting in an increase in the LDL-CH/HDL-CH ratio, which is an event highly associated with the risk of coronary heart disease in some populations [7]. In this context, some dietary guidelines report that dietary cholesterol intake of more than $300 \mathrm{mg} /$ day or consumption of more than four egg yolks per week could cause harm to human health [8]. In addition, intensive farming practices for commercial egg production lead to increasing stress and sensitivity of laying hens to any unfavorable conditions [9]. The physiological status, inflammation, antioxidant defense, and adrenal hormones of laying hens are factors that are influenced by stress [10]. In commercial poultry, stressors such as heat, fasting, dehydration, transportation, and caging cause an increase in corticosterone secretion, which is known in birds as a stress hormone [11,12]. Lipid peroxidation is another indicator for the oxidative stress status, and many studies have evidenced its correlation with atherosclerotic CVD $[13,14]$. Such stress markers and other markers such as plasma protein and $\mathrm{T}_{3}$ hormone could be used, at the same time, as indicators reflecting the physiological performance of laying hens [15-17].

In recent years, a variety of natural products and medicinal plants have been widely accepted as alternative nutritional strategies for lowering egg cholesterol, maintaining the performance, and improving the productivity of laying hens [18-20]. Citrullus colocynthis (CC) belongs to the cucurbitaceous plant family and commonly grows in desert areas, including Egypt and Saudi Arabia [21]. This plant is well known in many countries as a traditional medicine for the treatment of some chronic diseases [22]. Previous research reported that CC has a wide range of biological activities that protect tissues and cells against oxidation [23-25], diabetes [23,26], hyperlipidemia [27,28], microbial infection [29,30], and inflammation [31,32]. It was also shown that CC possesses a high nutritional value due to its high contents of proteins, essential minerals, and beneficial fatty acids [33].

Most pharmacological and nutritional properties of CC have been studied in human or mammalian animals, such as rabbits and rats. For example, a significant decrease in total cholesterol, triglycerides, phospholipids, and lipid peroxidation was found in the serum and liver of diabetic rats treated with the ethanol extract of CC fruits at a dosage of $300 \mathrm{mg} / \mathrm{kg}$ [23]. Additionally, administration of CC seeds to hyperlipidemic patients [27] or rabbits [28] induced a significant reduction in serum cholesterol and triglycerides. An anti-inflammatory effect was also observed in rats intraperitoneally injected with $4 \mathrm{mg} / \mathrm{kg}$ of a water extract of fresh CC [32]. In contrast, there is no updated research available on the possible effect of CC administration to poultry species. Therefore, the current study was carried out to evaluate, for the first time, the impact of inclusion of extracted CC seeds into layer diets on the lipid profile, stress indicators, physiological status, and productive performance of laying hens.

\section{Materials and Methods}

\subsection{Ethical Statement}

All experimental protocols in the present study were compliant with the relevant research ethics guidelines of King Faisal University and the National Committee of Medical and Bioethics. Ethical approval for the study was obtained from the Research Ethics Committee (REC) at King Faisal University (KFU-REC/2021-02-17). 


\subsection{Seed Extraction and Analysis}

CC fruits were obtained from different herbalists in Al-Ahsa, Saudi Arabia. Seeds were isolated manually from the pulp of the fruits, and then the collected seeds were dried and ground into a powder using a grinder (Moulinex Type LM201, Mayenne, France). The powder was then extracted three times using a mixture of $30 \%$ ethanol in distilled water. After that, the hydro-ethanol extracts were pooled and concentrated after removing ethanol residues by a vacuum evaporator at a maximum temperature of $50{ }^{\circ} \mathrm{C}$ [28]. The extracted CC seeds (ECCs) were kept as a powder in a clean, dark bottle at $4{ }^{\circ} \mathrm{C}$ until use in the experiment.

The chemical analysis of ECCs was performed following the methods of AOAC International [34] for caloric content (method 971.10), dry matter (method 930.15), crude fiber (method 920.169), total fat (method 950.54), crude protein (method 954.01), total ash (method 942.05), and calcium, potassium, magnesium, phosphorus, iron, and sodium minerals (method 985.35), and the results are presented in Table 1. In addition, ECCs were subjected to a qualitative phytochemical screening for the detection of various active chemical constituents according to methods described by Karumi et al. [35]. The presence of saponins was tested by foam appearance and persistence for at least $15 \mathrm{~min}$ after vigorous shaking of ECCs with distilled water. The presence of tannins was tested by the appearance of a green precipitate after adding ferric chloride reagent to a filtrated mixture of ECCs in distilled water. The presence of flavonoids was examined by Shinoda's test (cyanidin reaction) based on red/orange coloration after treating ECCs with metallic magnesium and concentrated hydrochloric acid. The reducing compounds were tested by observing brick-red precipitation resulting from boiling ECCs in Fehling's solution. The presence of alkaloids was tested by the appearance of turbidity or precipitation after treating the ECCs with Dragendorff's and Mayer's reagents. The presence of terpenoids was examined by the Liebermann-Burchard test based on the observation of a dark-green color when ECCs were treated with chloroform, acetic anhydride, and a few drops of sulfuric acid. The test for quinones was performed by treating a small amount of ECCs with concentrated hydrochloric acid and observing the formation of a yellow-colored precipitate. Finally, coumarins were examined by using the Erlich test based on the development of an orange color when ECCs were treated with a solution of dimethylamino-benzaldehyde ( $5 \%$ ethanol) and then acidified by hydrochloric acid. The results of phytochemical analysis revealed the presence of saponins, catechic tannins, flavonoids, and coumarins in the ECCs (Table 1).

Table 1. The chemical analysis and phytochemical screening of extracted Citrullus colocynthis seeds (ECCs).

\begin{tabular}{cccc}
\hline Chemical Analysis & Result $^{\mathbf{1}}$ & Phytochemical Screening & Result $^{\mathbf{2}}$ \\
\hline Dry matter (DM) & $94.09 \%$ & Saponins & + \\
Caloric content & $41.33 \mathrm{MJ}$ & Tannins & + \\
Crude fiber & $453.7 \mathrm{~g}$ & Flavonoids & + \\
Total fat & $172.9 \mathrm{~g}$ & Reducing compounds & - \\
Crude protein & $129.5 \mathrm{~g}$ & Alkaloids & - \\
Total ash & $25.8 \mathrm{~g}$ & Terpenoids & + \\
Calcium & $7.6 \mathrm{~g}$ & Quinones & \\
Potassium & $6.9 \mathrm{~g}$ & Coumarins & \\
Magnesium & $2.6 \mathrm{~g}$ & & \\
Phosphorus & $0.3 \mathrm{~g}$ & & \\
Iron & $0.2 \mathrm{~g}$ & & \\
Sodium & $0.1 \mathrm{~g}$ & & \\
\hline
\end{tabular}

${ }^{1}$ Results of chemical analyses calculated per kg DM. ${ }^{2}$ Positive test (+); negative test (-).

\subsection{Birds and Experimental Protocol}

Two hundred sixteen commercial Hy-Line brown laying hens (40-weeks-old) were settled in cages (3 layers/cage) in an open housing system. The hens were kept in standard 
environmental and hygienic conditions, with a photoperiod of $16 \mathrm{~h}$ light and $8 \mathrm{~h}$ darkness, and were provided with ad libitum water and feed throughout the experimental period. The hens were randomly allocated into four equal groups (18 replicates $\times 3$ hens each per group), including the control group, which received a basal diet without supplementation, and the experimental groups 1,2, and 3, which received a basal diet supplemented with $0.5,1.0$, and $2.0 \mathrm{~g}$ of ECCs per $\mathrm{kg}$ diet, respectively. The basal diet was formulated in grist form (Table 2) to meet the nutritional recommendations for brown commercial layers under the management guide of Hy-Line International (available at https:/ / www.hyline. com/varieties/brown. Accessed on 23 August 2021). ECCs powder was mixed daily with the basal diet before introducing it to the laying hens. The trials were continued for 12 consecutive weeks (from 40 to 52 weeks of age).

Table 2. The nutrient ingredients and calculated and determined chemical analyses of the basal diet.

\begin{tabular}{cc}
\hline Ingredients $^{\mathbf{1}}$ & Content $(\mathrm{g} / \mathrm{kg})$ \\
\hline Yellow corn & 565.5 \\
Soybean meal $(44 \%)$ & 276.0 \\
Wheat bran & 10.0 \\
Soybean oil & 30.0 \\
Bone meal & 30.0 \\
Limestone & 80.0 \\
Salt $(\mathrm{NaCl})$ & 4.0 \\
Premix & 3.0 \\
DL-methionine & 1.5 \\
\hline Calculated chemical analysis ${ }^{2}$ & \\
\hline Metabolizable energy $(\mathrm{MJ} / \mathrm{kg})$ & 1.26 \\
Crude protein $(\mathrm{g} / \mathrm{kg})$ & 174.7 \\
Calcium $(\mathrm{g} / \mathrm{kg})$ & 40.2 \\
Available phosphorus $(\mathrm{g} / \mathrm{kg})$ & 5.2 \\
Lysine $(\mathrm{g} / \mathrm{kg})$ & 9.5 \\
Methionine $(\mathrm{g} / \mathrm{kg})$ & 4.2 \\
Linoleic acid $(\mathrm{g} / \mathrm{kg})$ & 28.8 \\
\hline Determined chemical analysis ${ }^{2}$ & \\
\hline Dry matter $(\mathrm{g} / \mathrm{kg})$ & 890.0 \\
Crude protein $(\mathrm{g} / \mathrm{kg})$ & 167.5 \\
Crude fat $(\mathrm{g} / \mathrm{kg})$ & 66.0 \\
Crude fiber $(\mathrm{g} / \mathrm{kg})$ & 47.0 \\
Total ash $(\mathrm{g} / \mathrm{kg})$ & 129.0 \\
Calcium $(\mathrm{g} / \mathrm{kg})$ & 42.2 \\
Available phosphorus $(\mathrm{g} / \mathrm{kg})$ & 4.2 \\
\hline
\end{tabular}

${ }^{1}$ Ingredients were formulated as g per kg of the basal diet. ${ }^{2}$ Calculated and determined chemical analyses were expressed per $\mathrm{kg}$ of the basal diet. * Premix provided the following vitamins and minerals per $\mathrm{kg}$ of the basal diet: $8000 \mathrm{IU}$ of vitamin A, $1500 \mathrm{IU}$ of vitamin D, $4 \mathrm{mg}$ of riboflavin, $10 \mu \mathrm{g}$ of cobalamin, $15 \mathrm{mg}$ of vitamin E, $2 \mathrm{mg}$ of vitamin $\mathrm{K}, 500 \mathrm{mg}$ of choline, $25 \mathrm{mg}$ of niacin, $60 \mathrm{mg}$ of manganese, and $50 \mathrm{mg}$ of zinc.

\subsection{Productive Performance}

The total egg number (EN), egg weight (EW), and feed intake (FI) per cage were recorded daily during the whole experimental period. The average hen-day egg production $(\%)$, average EW $(\mathrm{g})$, and average FI (g) were then calculated for the entire experimental period per treatment group. The feed conversion ratio was calculated per cage on the basis of the total feed consumption per total egg mass $(\mathrm{EM}=\mathrm{EN} \times \mathrm{EW})$ during the whole experimental period.

\subsection{Blood Samples}

At the end of the experimental period (52 weeks of age), blood samples were collected from the brachial vein of 18 hens per treatment group (6 replicates per group) and transferred into heparinized tubes. To avoid handling stress, the birds were quickly bled 
within 3 min during the night [36]. Blood samples were centrifuged at $2000 \times g$ for $10 \mathrm{~min}$ at $4{ }^{\circ} \mathrm{C}$, and then the plasma was separated and stored at $-20^{\circ} \mathrm{C}$ until further assay of physiological parameters and stress indicators.

\subsubsection{Physiological Parameters}

Plasma total protein (TP), alanine amino transferase (ALT), and aspartate amino transferase (AST) concentrations were determined for each treatment group using available colorimetric kits (ab102535, ab241035, and ab105135, respectively; Abcam, Waltham, MA, USA). The concentration of triiodothyronine $\left(\mathrm{T}_{3}\right)$ was measured using ELISA diagnostic kits specific for chickens (MBS269454; MyBioSource, San Diego, CA, USA). The intra-assay and inter-assay coefficients of variability (CVs) for $\mathrm{T}_{3}$ analysis were less than $8 \%$ and $12 \%$, respectively, with a detection range of $0.3-20 \mu \mathrm{M} / \mathrm{mL}$.

\subsubsection{Stress Indicators}

Malondialdehyde (MDA) levels in the plasma were determined using quantitative colorimetric assay kits (ab118970; Abcam). Plasma corticosterone (CORT), tumor necrosis factor alpha $(\mathrm{TNF} \alpha)$, and heat shock protein 70 (HSP70) levels were quantified using ELISA kits specific for chickens (MBS701668, MBS2509660, and MBS2702636, respectively; MyBioSource). The intra-assay and inter-assay CVs were less than $8 \%$ and $10 \%$ for CORT, $5.57 \%$ and $5.89 \%$ for $\mathrm{TNF} \alpha$, and $10 \%$ and $12 \%$ for HSP70, respectively. The detection ranges were $0.5-20 \mathrm{ng} / \mathrm{mL}, 31.25-2000 \mathrm{pg} / \mathrm{mL}$, and $1.56-100 \mathrm{ng} / \mathrm{mL}$ for CORT, TNF $\alpha$, and HSP70, respectively.

\subsection{Lipid Profile}

At the end of the experiment ( 52 weeks of age), 18 hens per treatment group ( 3 hens per replicate $\times 6$ replicates per group) were fasted for $12 \mathrm{~h}$, then blood samples were obtained from the brachial vein into heparinized tubes, and plasma was separated, as mentioned above. Plasma triglycerides (TGs) were analyzed using colorimetric techniques of enzymatic diagnostic kits (ab65336, Abcam), while total plasma cholesterol $(\mathrm{CH})$, highdensity lipoprotein cholesterol (HDL-CH), and low-density lipoprotein cholesterol (LDL$\mathrm{CH}$ ) were separated and quantified according to the kits' protocols (ab65390, Abcam).

Livers were also removed from 18 hens per treatment group ( 3 hens per replicate $\times$ 6 replicates per group) after slaughtering at the end of the experiment (52 weeks of age) and were immediately stored at $-20^{\circ} \mathrm{C}$ until further processing. In addition, 18 eggs per group were gathered randomly in the last week of the experiment ( 3 eggs per replicate $\times$ 6 replicates per group) and broken to separate yolks for further analysis. Cholesterol was measured in the liver and egg yolk samples using cholesterol/cholesteryl ester detection kits (ab102515, Abcam) following the manufacturer's protocol with a minor modification. Briefly, $1 \mathrm{~g}$ of the liver/yolk sample was homogenized with $20 \mathrm{~mL}$ of chloroform:isopropanol:NP-40 lysis buffer (7:11:0.1) and then centrifuged for $5 \mathrm{~min}$ at $15,000 \times g$. The liquid phase was transferred to a new tube and dried under vacuum at $50{ }^{\circ} \mathrm{C}$ for $30 \mathrm{~min}$. The samples were then dissolved in $200 \mu \mathrm{L}$ of cholesterol assay buffer and vigorously shaken using a vortex until homogeneous. The cholesterol content in $50 \mu \mathrm{L}$ of reaction mixtures was determined at $450 \mathrm{~nm}$ against a standard curve generated using $0.25 \mathrm{mg} / \mathrm{mL}$ of cholesterol standard solution.

\subsection{Statistical Analysis}

The experimental unit for statistical analysis was the replicate (cage). Six replicates per group were statistically analyzed for the lipid profile, stress indicators, and physiological parameters, considering the promediate value of 3 samples per cage as a value of the replicate $(n=6)$, while the productive performance data of 3 hens per cage was averaged for the entire experimental period and used as a replicate for the statistical analysis $(n=18$ replicates per group). All data were statistically analyzed with the one-way analysis of variance (ANOVA) procedure with respect to the ECCs supplementation levels as 
independent variables. Orthogonal polynomial contrast and regression analyses were also performed to test the linear and quadratic trends in the increasing ECCs doses applied in the present study. Results were expressed as means \pm standard deviation (SD), and the differences between treatment groups were determined using Duncan's post hoc test. The level of statistical significance was set at $p<0.05$. All statistical analyses were performed using the SPSS software package (version 22.0; IBM Corp., Armonk, NY, USA, 2013).

\section{Results}

\subsection{Lipid Profile}

The effect of ECCs treatment on the lipid profile of laying hens is shown in Table 3. Plasma TG, $\mathrm{CH}$, and LDL-CH were significantly $(p<0.05)$ reduced, while plasma HDL-CH was significantly increased by ECCs inclusion in the diets of laying hens. Results showed that there was a significant linear effect of increasing doses of ECCs on the plasma lipid profile $\left(\mathrm{R}^{2}=97.3,97.0,96.4\right.$, and $80.4 \%$ for TG, $\mathrm{CH}$, LDL-CH, and HDL-CH, respectively; $p<0.05)$. It was found that ECCs at $0.5 \mathrm{~g} / \mathrm{kg}$ feed significantly $(p<0.05)$ decreased the liver and egg yolk $\mathrm{CH}$ compared to the control group. The higher doses of ECCs $(1.0-2.0 \mathrm{~g} / \mathrm{kg})$ significantly decreased the liver and egg yolk $\mathrm{CH}$ when compared to the lower doses $(0-0.5 \mathrm{~g} / \mathrm{kg})$, showing a linear trend $\left(\mathrm{R}^{2}=75.3\right.$ and $69.2 \%$, respectively) and a quadratic trend $\left(R^{2}=22.6\right.$ and $21.6 \%$, respectively).

Table 3. Effect of dietary extracted Citrullus colocynthis seeds (ECCs) supplementation on the lipid profile of laying hens.

\begin{tabular}{|c|c|c|c|c|c|c|}
\hline \multirow{2}{*}{$\begin{array}{l}\text { Dietary ECCs } \\
\text { Groups }\end{array}$} & Plasma TG & Plasma CH & $\begin{array}{c}\text { Plasma } \\
\text { HDL-CH }\end{array}$ & $\begin{array}{l}\text { Plasma } \\
\text { LDL-CH }\end{array}$ & Liver $\mathrm{CH}$ & Egg Yolk CH \\
\hline & (mg/dL) & (mg/dL) & (mg/dL) & (mg/dL) & (mg/g) & $(\mathrm{mg} / \mathrm{g})$ \\
\hline Control & $207.4 \pm 1.59^{a}$ & $152.3 \pm 1.54^{\mathrm{a}}$ & $40.8 \pm 2.27^{c}$ & $113.2 \pm 2.11^{\mathrm{a}}$ & $5.4 \pm 0.18^{a}$ & $12.3 \pm 0.43^{a}$ \\
\hline Group 1 & $200.0 \pm 1.83^{b}$ & $146.8 \pm 1.62^{b}$ & $42.3 \pm 2.18^{c}$ & $106.0 \pm 2.82^{b}$ & $4.2 \pm 0.11^{b}$ & $11.1 \pm 0.29^{b}$ \\
\hline Group 2 & $188.6 \pm 2.53^{c}$ & $135.5 \pm 2.69^{c}$ & $47.3 \pm 1.06^{b}$ & $89.8 \pm 3.05^{c}$ & $3.3 \pm 0.03^{c}$ & $10.4 \pm 0.07^{\mathrm{c}}$ \\
\hline \multirow[t]{2}{*}{ Group 3} & $173.1 \pm 2.32^{\mathrm{d}}$ & $120.3 \pm 1.68^{\mathrm{d}}$ & $54.1 \pm 4.17^{\mathrm{a}}$ & $67.6 \pm 4.08^{\mathrm{d}}$ & $3.2 \pm 0.09^{c}$ & $10.2 \pm 0.27^{c}$ \\
\hline & \multicolumn{6}{|c|}{ Polynomial contrast test; sum of squares ( $p$-value) } \\
\hline Combined & $\begin{array}{l}4008.929 \\
(<0.001)\end{array}$ & $\begin{array}{l}3581.897 \\
(<0.001)\end{array}$ & $647.676(<0.001)$ & $\begin{array}{c}7356.190 \\
(<0.001)\end{array}$ & $18.601(<0.001)$ & $17.142(<0.001)$ \\
\hline Linear term & $\begin{array}{c}3985.304 \\
(<0.001)\end{array}$ & $\begin{array}{l}3549.191 \\
(<0.001)\end{array}$ & $635.222(<0.001)$ & $\begin{array}{c}7273.272 \\
(<0.001)\end{array}$ & $14.206(<0.001)$ & $13.065(<0.001)$ \\
\hline \multirow[t]{2}{*}{ Quadratic term } & $2.613(0.451)$ & $0.454(0.732)$ & $3.101(0.516)$ & $5.839(0.444)$ & $4.263(<0.001)$ & $4.065(<0.001)$ \\
\hline & \multicolumn{6}{|c|}{ Regression analysis; $\mathbf{R}^{2}$ ( $p$-value) } \\
\hline Linear effect & $0.973(<0.001)$ & $0.970(<0.001)$ & $0.804(<0.001)$ & $0.964(<0.001)$ & $0.753(<0.001)$ & $0.692(<0.001)$ \\
\hline Quadratic effect & $0.000(0.486)$ & $0.001(0.769)$ & $0.004(0.519)$ & $0.000(0.507)$ & $0.226(<0.001)$ & $0.216(<0.001)$ \\
\hline
\end{tabular}

Data are presented as means \pm SD for six replicates per group $(n=6)$. Means within the same column with different superscripts are significantly different $(p<0.05)$. R-squared $\left(R^{2}\right)$ represents the linear and quadratic regression effects of increasing ECCs doses in diets on the lipid profile parameters of laying hens. Dietary ECCs groups: the control group received a basal diet without supplementation, while experimental groups 1, 2, and 3 received a basal diet supplemented with $0.5,1.0$, and $2.0 \mathrm{~g}$ of ECCs per kg feed, respectively. TG, triglyceride; $\mathrm{CH}$, cholesterol; HDL-CH, high-density lipoprotein cholesterol; LDL-CH, low-density lipoprotein cholesterol.

\subsection{Stress Indicators}

The effect of ECCs treatment on the plasma stress indicators of laying hens is presented in Table 4. A significant $(p<0.05)$ decrease was observed in the plasma MDA of laying hens supplemented with $1-2 \mathrm{~g} / \mathrm{kg}$ of ECCs compared to those hens supplemented with $0-0.5 \mathrm{~g} / \mathrm{kg}$ of ECCs. The plasma CORT, TNF $\alpha$, and HSP70 were significantly lowered $(p<0.05)$ by $0.5-2 \mathrm{~g} / \mathrm{kg}$ of ECCs compared to the control group. Moreover, there was a significant $(p<0.05)$ linear effect of increasing doses of ECCs on the plasma stress indicators, whereas the quadratic effect was found to be statistically insignificant $(p>0.05)$. Results also showed that increasing doses of ECCs were highly correlated with plasma CORT and MDA $\left(R^{2}=88.1\right.$ and $73.8 \%$, respectively) than with TNF $\alpha$ and HSP70 $\left(R^{2}=52.3\right.$ and $52.9 \%$, respectively) of laying hens. 
Table 4. Effect of dietary extracted Citrullus colocynthis seeds (ECCs) supplementation on some stress indicators of laying hens.

\begin{tabular}{|c|c|c|c|c|}
\hline \multirow{2}{*}{$\begin{array}{l}\text { Dietary ECCs } \\
\text { Groups }\end{array}$} & MDA & CORT & TNF $\alpha$ & HSP70 \\
\hline & $(\mu \mathrm{M} / \mathrm{mL})$ & (ng/mL) & $(\mathrm{pg} / \mathrm{mL})$ & (ng/mL) \\
\hline Control & $2.84 \pm 0.174^{\mathrm{a}}$ & $4.88 \pm 0.129^{a}$ & $94.62 \pm 0.515^{\mathrm{a}}$ & $24.13 \pm 0.897^{a}$ \\
\hline Group 1 & $2.64 \pm 0.386^{\mathrm{a}}$ & $4.35 \pm 0.288^{b}$ & $93.37 \pm 0.683^{b}$ & $23.39 \pm 1.188^{b}$ \\
\hline Group 2 & $2.14 \pm 0.190^{b}$ & $3.72 \pm 0.338^{c}$ & $93.25 \pm 0.649^{b}$ & $22.07 \pm 1.069^{b}$ \\
\hline \multirow[t]{2}{*}{ Group 3} & $1.79 \pm 0.167^{\mathrm{c}}$ & $3.01 \pm 0.243^{d}$ & $92.34 \pm 1.038^{c}$ & $21.34 \pm 1.006^{\mathrm{c}}$ \\
\hline & \multicolumn{4}{|c|}{ Polynomial contrast test; sum of squares ( $p$-value) } \\
\hline Combined & $4.112(<0.001)$ & $11.726(<0.001)$ & $15.812(<0.001)$ & $28.484(<0.001)$ \\
\hline Linear term & $3.931(<0.001)$ & $11.529(<0.001)$ & $14.095(<0.001)$ & $26.611(<0.001)$ \\
\hline \multirow[t]{2}{*}{ Quadratic term } & $0.052(0.367)$ & $0.158(0.143)$ & $0.813(0.242)$ & $1.156(0.316)$ \\
\hline & \multicolumn{4}{|c|}{ Regression analysis; $\mathbf{R}^{2}$ ( $p$-value) } \\
\hline Linear effect & $0.738(<0.001)$ & $0.881(<0.001)$ & $0.523(<0.001)$ & $0.529(<0.001)$ \\
\hline Quadratic effect & $0.010(0.379)$ & $0.012(0.139)$ & $0.030(0.248)$ & $0.023(0.311)$ \\
\hline
\end{tabular}

Data are presented as means \pm SD for six replicates per group $(n=6)$. Means within the same column with different superscripts are significantly different $(p<0.05)$. R-squared $\left(R^{2}\right)$ represents the linear and quadratic regression effects of increasing ECCs doses in diets on the stress indicators of laying hens. Dietary ECCs groups: the control group received a basal diet without supplementation, while experimental groups 1,2, and 3 received a basal diet supplemented with $0.5,1.0$, and $2.0 \mathrm{~g}$ of ECCs per $\mathrm{kg}$ feed, respectively. MDA, plasma malondialdehyde; CORT, plasma corticosterone; TNF $\alpha$, plasma tumor necrosis factor alpha; HSP70, plasma heat shock protein 70.

\subsection{Physiological Parameters}

The effect of ECCs treatment on the physiological parameters of laying hens is shown in Table 5. Supplementing the diet with ECCs at $1.0 \mathrm{~g} / \mathrm{kg}$ significantly $(p<0.05)$ increased the plasma $\mathrm{TP}$ and $\mathrm{T}_{3}$ by $17.5 \%$ and $46.2 \%$, respectively, compared to the control group. Increasing the level of ECCs in the diet to $2.0 \mathrm{~g} / \mathrm{kg}$ induced a linear increase in the plasma $\mathrm{TP}$ and $\mathrm{T}_{3}$ of laying hens $\left(\mathrm{R}^{2}=69.3 \%\right.$ and $85 \%$, respectively; $\left.p<0.05\right)$. In contrast, supplementing the diets with $1.0-2.0 \mathrm{~g} / \mathrm{kg}$ of ECCs significantly $(p<0.05)$ decreased the plasma ALT and AST of laying hens compared to the hens supplemented with $0-0.5 \mathrm{~g} / \mathrm{kg}$ of ECCs. Moreover, increasing the ECCs doses had significant $(p<0.05)$ linear and quadratic effects that explained $57.5 \%$ and $10.5 \%$ of the total variance for ALT and $67.2 \%$ and $15.4 \%$ of the total variance for AST, respectively.

\subsection{Productive Performance}

Results of the productive performance of laying hens that fed on diets with or without ECCs supplementation are represented in Table 6. The ECCs treatment at $1.0-2.0 \mathrm{~g} / \mathrm{kg}$ significantly $(p<0.05)$ increased the hen-day egg production by at least 2.5 p.p. compared to the ECCs treatment at $0-0.5 \mathrm{~g} / \mathrm{kg}$. The average egg weight was significantly $(p<0.05)$ increased in all experimental groups by approximately $0.6,1.3$, and $2.2 \mathrm{~g}$ in the groups treated with $0.5,1.0$, and $2.0 \mathrm{~g} / \mathrm{kg}$ of ECCs, respectively, compared to the control group. In contrast, the feed intake of laying hens was significantly $(p<0.05)$ reduced by $3.1 \%$ and $4.2 \%$ in the groups treated with 0.1 and $2.0 \mathrm{~g} / \mathrm{kg}$ of ECCs, respectively, compared to the control group. The feed conversion ratio of hens treated with 1.0 and $2.0 \mathrm{~g} / \mathrm{kg}$ of ECCs was significantly $(\mathrm{P}<0.05)$ improved by approximately $7.9 \%$ and $10.8 \%$, respectively, compared to the control group. Furthermore, it was found that the egg production and egg weight of laying hens were significantly increased in a linear trend with increasing doses of ECCs in the diets $\left(R^{2}=39.5 \%\right.$ and $70.2 \%$, respectively; $\left.p<0.05\right)$. In contrast, feed intake and feed conversion ratio were significantly decreased in a linear trend with increasing doses of ECCs in the diets $\left(\mathrm{R}^{2}=72.9 \%\right.$ and $75.9 \%$, respectively; $\left.p<0.05\right)$, while the quadratic effect of ECCs doses on the productive performance was not significant $(p>0.05)$. 
Table 5. Effect of dietary extracted Citrullus colocynthis seeds (ECCs) supplementation on some physiological parameters of laying hens.

\begin{tabular}{|c|c|c|c|c|}
\hline \multirow{2}{*}{ Dietary ECCs Groups } & TP & $\mathbf{T}_{3}$ & ALT & AST \\
\hline & $(g / d L)$ & $(\mu \mathrm{M} / \mathrm{mL})$ & $(\mathrm{U} / \mathrm{mL})$ & $(\mathrm{U} / \mathrm{mL})$ \\
\hline Control & $4.63 \pm 0.579^{c}$ & $5.69 \pm 0.859^{c}$ & $13.71 \pm 1.344^{\mathrm{a}}$ & $30.88 \pm 2.635^{\mathrm{a}}$ \\
\hline Group 1 & $4.99 \pm 0.122 \mathrm{bc}$ & $6.15 \pm 0.544^{\mathrm{c}}$ & $12.41 \pm 1.421^{\mathrm{a}}$ & $25.46 \pm 1.551^{\mathrm{b}}$ \\
\hline Group 2 & $5.44 \pm 0.298^{b}$ & $8.32 \pm 0.619^{b}$ & $10.10 \pm 0.894^{b}$ & $21.99 \pm 1.337^{\mathrm{c}}$ \\
\hline Group 3 & $6.05 \pm 0.379^{\mathrm{a}}$ & $10.05 \pm 0.627^{\mathrm{a}}$ & $9.92 \pm 0.459^{b}$ & $20.73 \pm 2.133^{c}$ \\
\hline & \multicolumn{4}{|c|}{ Polynomial contrast test; sum of squares ( $p$-value) } \\
\hline Combined & $6.713(<0.001)$ & $73.422(<0.001)$ & $61.039(<0.001)$ & $\begin{array}{l}371.368 \\
(<0.001)\end{array}$ \\
\hline Linear term & $6.671(<0.001)$ & $70.065(<0.001)$ & $48.976(<0.001)$ & $\begin{array}{l}302.328 \\
(<0.001)\end{array}$ \\
\hline \multirow[t]{2}{*}{ Quadratic term } & $0.026(0.680)$ & $0.046(0.754)$ & $8.970(0.013)$ & $69.039(<0.001)$ \\
\hline & \multicolumn{4}{|c|}{ Regression analysis; $\mathbf{R}^{2}$ ( $p$-value) } \\
\hline Linear effect & $0.693(<0.001)$ & $0.850(<0.001)$ & $0.575(<0.001)$ & $0.672(<0.001)$ \\
\hline Quadratic effect & $0.003(0.673)$ & $0.000(0.784)$ & $0.105(0.016)$ & $0.154(<0.001)$ \\
\hline
\end{tabular}

Data are presented as means \pm SD for six replicates per group $(n=6)$. Means within the same column with different superscripts are significantly different $(p<0.05)$. R-squared $\left(\mathbf{R}^{2}\right)$ represents the linear and quadratic regression effects of increasing ECCs doses in diets on the physiological parameters of laying hens. Dietary ECCs groups: the control group received a basal diet without supplementation, while experimental groups 1,2 , and 3 received a basal diet supplemented with $0.5,1.0$, and $2.0 \mathrm{~g}$ of ECCs per $\mathrm{kg}$ feed, respectively. TP, plasma total protein; $\mathrm{T}_{3}$, plasma triiodothyronine; ALT, plasma alanine amino transferase; AST, plasma aspartate amino transferase.

Table 6. Effect of dietary extracted Citrullus colocynthis seeds (ECCs) supplementation on the productive performance of laying hens.

\begin{tabular}{|c|c|c|c|c|}
\hline \multirow{2}{*}{$\begin{array}{l}\text { Dietary ECCs } \\
\text { Groups }\end{array}$} & $\begin{array}{c}\text { Egg } \\
\text { Production }\end{array}$ & Egg Weight & Feed Intake & Feed Conversion \\
\hline & $(\%)$ & (g) & $(g / d)$ & (kg FI/kg EM) \\
\hline Control & $91.0 \pm 1.51^{b}$ & $62.1 \pm 0.48^{d}$ & $114.3 \pm 0.88^{\mathrm{a}}$ & $2.03 \pm 0.044^{\mathrm{a}}$ \\
\hline Group 1 & $91.5 \pm 2.36^{b}$ & $62.7 \pm 0.67^{\mathrm{c}}$ & $114.7 \pm 0.90^{\mathrm{a}}$ & $2.00 \pm 0.061^{\mathrm{a}}$ \\
\hline Group 2 & $93.3 \pm 1.08^{\mathrm{a}}$ & $63.4 \pm 0.57^{b}$ & $110.8 \pm 1.07^{b}$ & $1.87 \pm 0.032^{b}$ \\
\hline \multirow[t]{2}{*}{ Group 3} & $94.3 \pm 1.09^{a}$ & $64.3 \pm 0.47^{\mathrm{a}}$ & $109.5 \pm 0.53^{c}$ & $1.81 \pm 0.028^{c}$ \\
\hline & \multicolumn{4}{|c|}{ Polynomial contrast test; sum of squares ( $p$-value) } \\
\hline Combined & $\begin{array}{l}126.775 \\
(<0.001)\end{array}$ & $51.092(<0.001)$ & $\begin{array}{l}359.014 \\
(<0.001)\end{array}$ & $0.596(<0.001)$ \\
\hline Linear term & $\begin{array}{l}118.734 \\
(<0.001)\end{array}$ & $50.518(<0.001)$ & $\begin{array}{l}298.909 \\
(<0.001)\end{array}$ & $0.549(<0.001)$ \\
\hline \multirow[t]{2}{*}{ Quadratic term } & $1.819(0.402)$ & $0.386(0.266)$ & $0.721(0.331)$ & $0.006(0.077)$ \\
\hline & \multicolumn{4}{|c|}{ Regression analysis; $\mathbf{R}^{2}$ ( $p$-value) } \\
\hline Linear effect & $0.395(<0.001)$ & $0.702(<0.001)$ & $0.729(<0.001)$ & $0.759(<0.001)$ \\
\hline Quadratic effect & $0.006(0.407)$ & $0.006(0.264)$ & $0.001(0.505)$ & $0.008(<0.120)$ \\
\hline
\end{tabular}

Data are presented as means \pm SD for 18 replicates per group $(n=18)$. Means within the same column with different superscripts are significantly different $(p<0.05)$. R-squared $\left(R^{2}\right)$ represents the linear and quadratic regression effects of increasing ECCs doses in diets on the productive performance of laying hens. Dietary ECCs groups: the control group received a basal diet without supplementation, while experimental groups 1, 2, and 3 received a basal diet supplemented with $0.5,1.0$, and $2.0 \mathrm{~g}$ of ECCs per $\mathrm{kg}$ feed, respectively. FI, feed intake; EM, egg mass. All productive parameters were calculated as an average of the entire experimental period (12 weeks).

\section{Discussion}

The doses of ECCs used in the current study were determined based on a preliminary study on a group of laying hens. It was found that notable effects of ECCs on the egg productivity of laying hens are obtained at levels of $0.5-2.0 \mathrm{~g}$ per $\mathrm{kg}$ of diet, while adverse effects are observed at higher levels. These levels were used in the present study, and 
they were safe and did not display any signs of toxicity on the laying hens during the experimental period.

Results demonstrated that basal diets supplemented with ECCs lower the lipid profile by decreasing plasma TG, $\mathrm{CH}$, and LDL-CH, as well as decreasing liver and egg yolk $\mathrm{CH}$, while increasing plasma HDL-CH. These results may present the most important advantage of ECCs inclusion into layer diets in view of producing healthier eggs that contain lower yolk $\mathrm{CH}$ for humans [3], especially the elderly, who are more susceptible to the chronic inflammatory disease of the arteries, atherosclerosis [2]. Such antilipidemic activity of CC seeds has been widely demonstrated in previous studies on both animals and humans [33]. It was found that the ethanolic extract of CC plants lowers the TG and $\mathrm{CH}$ levels in hyperlipidemic rabbits [28] and that administration of CC seed powder to hyperlipidemic non-diabetic patients also lowers the TG and $\mathrm{CH}$ levels [27]. Furthermore, a significant reduction in hyperlipidemia was induced by the administration of CC extracts to diabetic rats [23]. The hypotriglyceridemic and hypocholesterolemic effects of ECCs may be due to the catabolism or removal of lipoproteins in the liver [37] and the inhibition of specific hepatic enzymes responsible for lysosomal lipid hydrolysis [38]. Dallak et al. [39] also reported that CC pulp extracts depress the hepatic gluconeogenesis and lipogenesis in diabetic rats through downregulation of gluconeogenetic enzymes and increasing of insulin secretion. The phytochemical screening of ECCs in the present study revealed the presence of saponins and catechic tannins, which are bioactive components that contribute to hypolipidemic activity [25]. It is known that both components can participate in the suppression of lipid and cholesterol absorption in the gut via dietary fat $\beta$-oxidation, enzymatic $\mathrm{CH}$ biosynthesis inhibition, and/or interference with $\mathrm{CH}$-micellar affinity [40,41]. Due to the intensive system of modern egg production and the continuous selection for high egg yield, commercial laying hens commonly are stressed and sensitive to any unfavorable conditions [12]. Plasma MDA levels are the principal measurement for oxidative stress status in animal plasma and tissues [13]. The lower MDA levels in the hens treated with ECCs may be attributed to the direct free-radical-scavenging activity of polyphenols and flavonoids in the ECCs [25,42]. In birds, CORT is the main end product of the hypothalamic-pituitary-adrenal (HPA) axis response to stress [11]. So, lower plasma CORT levels in laying hens treated with ECCs suggests that ECC treatment can alleviate the stress induced by intensive production management in laying hens [43]. However, lower blood CORT in the ECC-treated groups can also be associated more with the lower blood cholesterol levels shown in the same groups [44]. Moreover, the TNF $\alpha$ and HSP70 in laying hens were significantly decreased by ECC treatment, whereas $T N F \alpha$, as a proinflammatory cytokine, plays a critical role in inflammation and immune responses during stress [45] and HSP70 is mainly synthesized to protect stressed cells [46]. The reduction in plasma TNF $\alpha$ in ECC-treated groups may be explained by the decrease in CORT in the ECC-treated groups, as this correlation between CORT secretion and TNF $\alpha$ expression has been previously reported in stressed mice [47,48]. In contrast, HSP70 expression can be promoted more as a consequence of the elevated levels of MDA in order to protect cells against peroxidation damage [49], and this may explain the lower levels of both HSP70 and MDA in the ECC-treated groups in the present study.

The reduction in plasma ALT and AST levels could indicate that ECCs can maintain the liver functions of layers. Similar effects of CC extracts were obtained in rats [50]; moreover, CC treatment can ameliorate the deleterious effects of heat stress on liver tissues of broilers [51]. The increased plasma TP in ECC-treated groups may be also due to such hepatoprotective properties of CC extracts. It was reported that a healthy liver orchestrates the metabolism of proteins and amino acids [52]. It was further reported that the hepatoprotective activity of medicinal fungus in rats increases plasma albumin, which is the major plasma protein produced by the liver and then circulated in the bloodstream [16]. Moreover, ECC treatment increased plasma $T_{3}$ in the present study, thereby increasing metabolism [17] and, consequently, improving the performance of laying hens [53]. 
In general, layer productive performance was enhanced in a linear trend by increasing the doses of ECCs. The positive effects of ECCs on layer egg production and egg weight could be correlated to the availability of protein, essential amino acids, and fatty acids in CC extracts [54]. As mentioned earlier, the bioactive components of ECCs alleviated stress; therefore, birds treated with ECCs suppressed the HPA axis pathway and displayed low levels of CORT. Consequent to the opposite effect of CORT on FI [55], it was expected that FI would increase in these groups; instead, it significantly decreased (Table 6). The decreased FI in the ECC-treated groups may be due to the bitter taste of CC seeds, which may affect the palatability of the diet [56]. In contrast, the gastrointestinal tract in the ECC-treated groups seems to be more efficient in the digestibility and bioavailability of nutrients due to the possible antimicrobial effect of tannins and flavonoids presented in the CC extracts [57]. However, neither the cecal microbiota nor the antimicrobial effect were analyzed in the present study. Furthermore, while activation of the HPA-CORT pathway increases the energy expenditure to maintain the immunity and survival of laying hens, the extremely inhibitory effect of ECC treatment on CORT may trigger energy investment from maintenance toward productivity [58]. Taking together, the positive events displayed as a result of ECC treatment in the present study, such as alleviating stress and improving the physiological status, could be considered a great suppressor for intestinal and reproductive pathologies, thus enhancing the performance of laying hens [59].

\section{Conclusions}

The dietary supplementation of ECCs at the level of $0.5 \mathrm{~g} / \mathrm{kg}$ had limited effects on layer performance. However, higher levels of ECCs at 1.0 and $2.0 \mathrm{~g} / \mathrm{kg}$ showed a significant improvement in the productive and physiological performance of laying hens. In addition, there was a significant hypolipidemic effect and stress alleviation in laying hens after inclusion of ECCs into diets at the three levels, compared to the control group, whereas the highest levels were observed with $2.0 \mathrm{~g} / \mathrm{kg}$ of ECCs. Furthermore, a high linear correlation was noticed between increasing doses of ECCs and MDA, liver $\mathrm{CH}$, and egg yolk $\mathrm{CH}$ concentrations and egg weight, feed intake, and feed conversion ratio; moreover, the correlation was extremely high with the levels of TG, CH, LDL-CH, HDL-CH, and CORT. These results indicate that dietary supplementation with $2.0 \mathrm{~g} / \mathrm{kg}$ of ECCs could be a promising nutritional approach to producing healthier, lower-cholesterol eggs for consumers, in addition to enhancing the physiological and productive performance of laying hens by alleviating the stress of intensive commercial production.

Author Contributions: Conceptualization, M.I.A., A.A.A., A.O.A. and G.M.K.M.; methodology, M.I.A., A.A.A. and A.O.A.; validation, G.F.G., G.M.K.M. and E.S.M.; formal analysis, F.S.N., G.M.K.M., G.F.G. and E.S.M.; investigation, M.I.A., A.A.A., A.O.A., G.M.K.M., G.F.G., H.K.A.E.-A. and E.S.M.; resources, M.I.A., A.A.A. and H.K.A.E.-A.; data curation, A.O.A., G.M.K.M. and H.K.A.E.-A.; writingoriginal draft, G.M.K.M. and A.O.A.; writing-review and editing, G.M.K.M., G.F.G. and E.S.M.; visualization, A.O.A. and H.K.A.E.-A.; supervision, A.O.A.; project administration, A.O.A.; funding acquisition, M.I.A., A.A.A., A.O.A. and G.M.K.M. All authors have read and agreed to the published version of the manuscript.

Funding: This research was supported by funds obtained from the College of Agricultural and Food Sciences at King Faisal University and from the General Scientific Research Department at Cairo University (GSRD-CU; http:/ / gsrd.cu.edu.eg/. Accessed on 23 August 2021).

Institutional Review Board Statement: The study was conducted according to the guidelines of King Faisal University and the National Committee of Medical and Bioethics and approved by the Research Ethics Committee (REC) at King Faisal University (KFU-REC/2021-02-17).

Data Availability Statement: Not applicable.

Conflicts of Interest: The authors declare no conflict of interest. The funders had no role in the design of the study; in the collection, analyses, or interpretation of data; in the writing of the manuscript; or in the decision to publish the results. 


\section{References}

1. Jeloka, T.K.; Pandit, M.; Dharmatti, G.; Jamdade, T. Are oral protein supplements helpful in the management of malnutrition in dialysis patients? Indian J. Nephrol. 2013, 23, 1-4. [CrossRef] [PubMed]

2. Lewington, S.; Whitlock, G.; Clarke, R.; Sherliker, P.; Emberson, J.; Halsey, J.; Qizilbash, N.; Peto, R.; Collins, R. Blood cholesterol and vascular mortality by age, sex, and blood pressure: A meta-analysis of individual data from 61 prospective studies with 55000 vascular deaths. Lancet 2007, 370, 1829-1839. [CrossRef] [PubMed]

3. Weggemans, R.M.; Zock, P.; Katan, M.B. Dietary cholesterol from eggs increases the ratio of total cholesterol to high-density lipoprotein cholesterol in humans: A meta-analysis. Am. J. Clin. Nutr. 2001, 73, 885-891. [CrossRef] [PubMed]

4. Law, M.R.; Wald, N.J.; Rudnicka, A. Quantifying effect of statins on low density lipoprotein cholesterol, ischaemic heart disease, and stroke: Systematic review and meta-analysis. BMJ 2003, 326, 1423. [CrossRef] [PubMed]

5. Keast, D.R.; Fulgoni, V.L.; Nicklas, T.A.; O'Neil, C.E. Food sources of energy and nutrients among children in the United States: National Health and Nutrition Examination Survey 2003-2006. Nutrients 2013, 5, 283-301. [CrossRef] [PubMed]

6. O'Neil, C.E.; Keast, D.R.; Fulgoni, V.L.; Nicklas, T.A. Food sources of energy and nutrients among adults in the US: NHANES 2003-2006. Nutrients 2012, 4, 2097-2120. [CrossRef] [PubMed]

7. Fernandez, M.L.; Webb, D. The LDL to HDL cholesterol ratio as a valuable tool to evaluate coronary heart disease risk. J. Am. Coll. Nutr. 2008, 27, 1-5. [CrossRef]

8. Mozaffarian, D.; Ludwig, D. The 2015 US dietary guidelines. JAMA 2015, 313, 2421-2422. [CrossRef]

9. Downing, J.A.; Bryden, W.L. A non-invasive test of stress in laying hens. RIRDC Publ. 2002, 1-118.

10. Lara, L.; Rostagno, M.H. Impact of heat stress on poultry production. Animals 2013, 3, 356-369. [CrossRef]

11. Charmandari, E.; Tsigos, C.; Chrousos, G. Endocrinology of the stress response. Annu. Rev. Physiol. 2005, 67, 259-284. [CrossRef]

12. Singh, R.; Cook, N.; Cheng, K.M.; Silversides, F.G. Invasive and noninvasive measurement of stress in laying hens kept in conventional cages and in floor pens. Poult. Sci. 2009, 88, 1346-1351. [CrossRef]

13. Pham-Huy, L.A.; He, H.; Pham-Huy, C. Free radicals, antioxidants in disease and health. Int. J. Biomed. Sci. 2008, 4, 89-96.

14. Bahoran, T.; Soobrattee, M.; Luximon-Ramma, V.; Aruoma, O. Free radicals and antioxidants in cardiovascular health and disease. Internet J. Med. Update 2007, 1, 25-41. [CrossRef]

15. Mumma, J.O.; Thaxton, J.P.; Vizzier-Thaxton, Y.; Dodson, W.L. Physiological stress in laying hens. Poult. Sci. 2006, 85, 761-769. [CrossRef] [PubMed]

16. Chiu, H.-W.; Hua, K.-F. Hepatoprotective effect of wheat-based solid-state fermented Antrodia cinnamomea in carbon tetrachlorideinduced liver injury in rat. PLoS ONE 2016, 11, e0153087. [CrossRef]

17. Al-Ardi, M.H. The uses of gold nanoparticles and Citrullus colocynthis L. nanoparticles against Giardia lamblia in vivo. Clin. Epidemiol. Glob. Health 2020, 8, 1282-1286. [CrossRef]

18. Alaqil, A.; Abbas, A.; El-Beltagi, H.; El-Atty, H.; Mehaisen, G.; Moustafa, E. Dietary supplementation of probiotic Lactobacillus acidophilus modulates cholesterol levels, immune response, and productive performance of laying hens. Animals 2020, 10, 1588. [CrossRef]

19. Abbas, A.; Alaqil, A.; El-Beltagi, H.; El-Atty, H.A.; Kamel, N. Modulating laying hens productivity and immune performance in response to oxidative stress induced by E. coli challenge using dietary propolis supplementation. Antioxidants $2020,9,893$. [CrossRef] [PubMed]

20. Hazrati, S.; Rezaeipour, V.; Asadzadeh, S. Effects of phytogenic feed additives, probiotic and mannan-oligosaccharides on performance, blood metabolites, meat quality, intestinal morphology, and microbial population of Japanese quail. Br. Poult. Sci. 2019, 61, 132-139. [CrossRef]

21. Gurudeeban, S.; Satyavani, K.; Ramanathan, T. Bitter apple (Citrullus colocynthis): An overview of chemical composition and biomedical potentials. Asian J. Plant Sci. 2010, 9, 394-401. [CrossRef]

22. Qureshi, R.; Raza Bhatti, G.; Memon, R.A. Ethnomedicinal uses of herbs from northern part of Nara desert, Pakistan. Pak. J. Bot. 2010, 42, 839-851.

23. Dallak, M. In vivo, hypolipidemic and antioxidant effects of Citrullus colocynthis pulp extract in alloxan-induced diabetic rats. Afr. J. Biotechnol. 2011, 10, 9898-9903. [CrossRef]

24. Marzouk, Z.; Marzouk, B.; Mahjoub, M.A.; Haloui, E.; Mighri, Z.; Aouni, M.; Fenina, N. Screening of the antioxidant and the free radical scavenging potential of Tunisian Citrullus colocynthis Schrad. from Mednine. J. Food Agric. Environ. 2010, 8, $261-265$.

25. Kumar, S.; Kumar, D.; Jusha, M.; Saroha, K.; Singh, N.; Vashishta, B. Antioxidant and free radical scavenging potential of Citrullus colocynthis (L.) Schrad. methanolic fruit extract. Acta Pharm. 2008, 58, 215-220. [CrossRef] [PubMed]

26. Huseini, H.F.; Darvishzadeh, F.; Heshmat, R.; Jafariazar, Z.; Raza, M.; Larijani, B. The clinical investigation of Citrullus colocynthis (L.) schrad fruit in treatment of Type II diabetic patients: A randomized, double blind, placebo-controlled clinical trial. Phytother. Res. 2009, 23, 1186-1189. [CrossRef]

27. Rahbar, A.R.; Nabipour, I. The hypolipidemic effect of Citrullus colocynthis on patients with hyperlipidmia. Pak. J. Biol. Sci. 2010, 13, 1202-1207. [CrossRef] [PubMed]

28. Daradka, H.; Almasad, M.M.; Qazan, W.S.; El-Banna, N.M.; Samara, O.H. Hypolipidaemic effects of Citrullus colocynthis L. in rabbits. Pak. J. Biol. Sci. 2007, 10, 2768-2771. [CrossRef] [PubMed]

29. Najafi, S.; Sanadgol, N.; Nejad, B.S.; Beiragi, M.A.; Sanadgol, E. Phytochemical screening and antibacterial activity of Citrullus colocynthis (Linn.) schrad against Staphylococcus aureus. J. Med. Plants Res. 2010, 4, 2321-2325. [CrossRef] 
30. Ali, A.A.; Alian, M.A.; Elmahi, H.A. Phytochemical analysis of some chemical metabolites of colocynth plant (Citrullus colocynths L.) and its activities as antimicrobial and antiplasmodial. J. Basic Appl. Sci. Res. 2013, 3, 228-236.

31. Aly, A.M.; Naddaf, A. Anti-inflammatory activities of Colocynth topical gel. J. Med. Sci. 2006, 6, $216-221$.

32. Marzouk, B.; Marzouk, Z.; Haloui, E.; Fenina, N.; Bouraoui, A.; Aouni, M. Screening of analgesic and anti-inflammatory activities of Citrullus colocynthis from southern Tunisia. J. Ethnopharmacol. 2010, 128, 15-19. [CrossRef] [PubMed]

33. Hussain, A.I.; Rathore, H.; Sattar, M.Z.; Chatha, S.A.S.; Sarker, S.D.; Gilani, A.H. Citrullus colocynthis (L.) Schrad (bitter apple fruit): A review of its phytochemistry, pharmacology, traditional uses and nutritional potential. J. Ethnopharmacol. 2014, 155, 54-66. [CrossRef] [PubMed]

34. AOAC Association of Official Analysis Chemists International. Official Methods of Analysis of AOAC International; AOAC International: Washington, DC, USA, 2005.

35. Karumi, Y.; Onyeyili, P.A.; Ogugbuaja, V.O. Identification of active principles of M. balsamina (balsam apple) leaf extract. J. Med. Sci. 2004, 4, 179-182.

36. Romero, L.M.; Reed, J.M. Collecting baseline corticosterone samples in the field: Is under 3 min good enough? Comp. Biochem. Physiol. A Mol. Integr. Physiol. 2005, 140, 73-79. [CrossRef]

37. Begley, M.; Hill, C.; Gahan, C.G.M. Bile salt hydrolase activity in probiotics. Appl. Environ. Microbiol. 2006, 72, 1729-1738. [CrossRef]

38. Schlager, S.; Vujic, N.; Korbelius, M.; Duta-Mare, M.; Dorow, J.; Leopold, C.; Rainer, S.; Wegscheider, M.; Reicher, H.; Ceglarek, U.; et al. Lysosomal lipid hydrolysis provides substrates for lipid mediator synthesis in murine macrophages. Oncotarget 2017, 8 , 40037-40051. [CrossRef]

39. Dallak, M.; Bashir, N.; Abbas, M.; Elessa, R.; Haidara, R.E.M.; Khalil, M.; Al-Khateeb, M.A. Concomitant down regulation of glycolytic enzymes, upregulation of gluconeogenic enzymes and potential hepato-nephro-protective effects following the chronic administration of the hypoglycemic, insulinotropic citrullus colocynthis pulp extract. Am. J. Biochem. Biotechnol. 2009, 5, 153-161. [CrossRef]

40. Raederstorff, D.G.; Schlachter, M.F.; Elste, V.; Weber, P. Effect of EGCG on lipid absorption and plasma lipid levels in rats. J. Nutr. Biochem. 2003, 14, 326-332. [CrossRef]

41. Zamani, M.; Rahimi, A.O.; Mahdavi, R.; Nikbakhsh, M.; Jabbari, M.V.; Rezazadeh, H.; Delazar, A.; Nahar, L.; Sarker, S.D. Assessment of anti-hyperlipidemic effect of Citrullus colocynthis. Rev. Bras. Farm. 2007, 17, 492-496. [CrossRef]

42. Tannin-Spitz, T.; Bergman, M.; Grossman, S. Cucurbitacin glucosides: Antioxidant and free-radical scavenging activities. Biochem. Biophys. Res. Commun. 2007, 364, 181-186. [CrossRef]

43. Caulfield, M.P.; Padula, M.P. HPLC MS-MS analysis shows measurement of corticosterone in egg albumen is not a valid indicator of chicken welfare. Animals 2020, 10, 821. [CrossRef] [PubMed]

44. Pavlík, A.; Sláma, P.; Mazalová, L.; Kabourková, E. Total cholesterol and corticosterone concentration relationship in blood plasma of laying hens. J. Microbiol. Biotechnol. Food Sci. 2016, 05, 17-19. [CrossRef]

45. Mocellin, S.; Rossi, C.; Pilati, P.; Nitti, D. Tumor necrosis factor, cancer and anticancer therapy. Cytokine Growth Factor Rev. 2005, 16, 35-53. [CrossRef]

46. Al-Aqil, A.; Zulkifli, I. Changes in heat shock protein 70 expression and blood characteristics in transported broiler chickens as affected by housing and early age feed restriction. Poult. Sci. 2009, 88, 1358-1364. [CrossRef] [PubMed]

47. Hayley, S.; Kelly, O.; Anisman, H. Corticosterone changes in response to stressors, acute and protracted actions of tumor necrosis factor- $\alpha$, and lipopolysaccharide treatments in mice lacking the tumor necrosis factor- $\alpha$ p 55 receptor gene. Neuroimmunomodulation 2004, 11, 241-246. [CrossRef] [PubMed]

48. Villar, S.R.; Ronco, M.T.; Bussy, R.F.; Roggero, E.; Lepletier, A.; Manarin, R.; Savino, W.; Pérez, A.R.; Bottasso, O. Tumor necrosis factor- $\alpha$ regulates glucocorticoid synthesis in the adrenal glands of trypanosoma cruzi acutely-infected mice. The role of TNF-R1. PLoS ONE 2013, 8, e63814. [CrossRef]

49. Kregel, K.C. Invited review: Heat shock proteins: Modifying factors in physiological stress responses and acquired thermotolerance. J. Appl. Physiol. 2002, 92, 2177-2186. [CrossRef]

50. Al-Ghaithi, F.; El-Ridi, M.R.; Adeghate, E.; Amiri, M.H. Biochemical effects of Citrullus colocynthis in normal and diabetic rats. Mol. Cell. Biochem. 2004, 261, 143-149. [CrossRef]

51. Alzarah, M.; Althobiati, F.; Abbas, A.; Mehaisen, G.; Kamel, N. Citrullus colocynthis seeds: A potential natural immune modulator source for broiler reared under chronic heat stress. Animals 2021, 11, 1951. [CrossRef]

52. Charlton, M.R. Protein metabolism and liver disease. Baillieres. Clin. Endocrinol. Metab. 1996, 10, 617-635. [CrossRef]

53. Elnagar, S.; Scheideler, S.; Beck, M. Reproductive hormones, hepatic deiodinase messenger ribonucleic acid, and vasoactive intestinal polypeptide-immunoreactive cells in hypothalamus in the heat stress-induced or chemically induced hypothyroid laying hen. Poult. Sci. 2010, 89, 2001-2009. [CrossRef]

54. Al-Snafi, A.E. Chemical constituents and pharmacological effects of Citrullus colocynthis-A review. Asian J. Pharm. Res. 2016, 6, 57-67.

55. Deng, W.; Dong, X.F.; Tong, J.M.; Zhang, Q. The probiotic Bacillus licheniformis ameliorates heat stress-induced impairment of egg production, gut morphology, and intestinal mucosal immunity in laying hens. Poult. Sci. 2012, 91, 575-582. [CrossRef]

56. Idoko, A.S.; Oladiji, A.T.; Ilouno, L.E. Growth performance of rats maintained on citrullus colocynthis seed coatbased diet. IOSR J. Biotechnol. Biochem. 2015, 1, 9-14. 
57. Marzouk, B.; Marzouk, Z.; Décor, R.; Edziri, H.; Haloui, E.; Fenina, N.; Aouni, M. Antibacterial and anticandidal screening of Tunisian Citrullus colocynthis Schrad. from Medenine. J. Ethnopharmacol. 2009, 125, 344-349. [CrossRef]

58. Wang, X.; Liu, L.; Zhao, J.; Jiao, H.; Lin, H. Stress impairs the reproduction of laying hens: An involvement of energy. World's Poult. Sci. J. 2017, 73, 845-856. [CrossRef]

59. Shini, S.; Shini, A.; Blackall, P. The potential for probiotics to prevent reproductive tract lesions in free-range laying hens. Anim. Prod. Sci. 2013, 53, 1298-1308. [CrossRef] 